\title{
TEACHING WRITING OF RECOUNT TEXT BY USING COMIC STRIPS
}

\author{
Samsul Arifin and Dina Riyanti \\ Universitas PGRI Madiun \\ samsul0442@gmail.com
}

\begin{abstract}
The objectives are to describe the implementation, the advantages, and the disadvantages of teaching writing of recount text by using Comic Strips for the tenth grade students of senior high school. The researcher uses qualitative research as an approach and descriptive research as type of research. The result shows that the stages of implementing Comic Strips media in the classroom are introducing the media, explaining and analyzing the recount text, redistributing the media with other topic, asking the students to read and pay attention to, writing a recount text based on the Comic Strips given, monitoring the students' difficulties, correcting their mistakes on writing the text, writing the final draft based on the teacher's suggestion and comment, submitting the final writing, reviewing and giving feedback to the lesson, and closing. The advantages of the implementation of the media are that, firstly, it can stimulate the students' imagination and creativity so that they can obtain greater ideas in order to make a good composition. Second, it gives students the clue of chronological events which then it helps students to memorize and visualize better. Third, it facilitates the students to develop their own ideas and arrange words into good sentences of recount text by understanding both the story of pictures and the conversations in English illustrated in dialogue balloons. The last the students can easily find new vocabularies from the texts of conversations being conveyed by the characters in the media. Meanwhile, the disadvantages are first, there are some students who still make mistakes especially on their grammar and vocabulary. Second, the students often forget about using right capitalization and punctuation. Based on the result of the study, it is suggested to use Comic Strips to improve the students' writing on other text types.
\end{abstract}

Keywords: recount text, comic strips,

\section{INTRODUCTION}

Writing is the process of thinking to invent ideas, thinking about how to express those ideas into good writing, and arranging the ideas into statements and paragraph clearly. It can also develop the writers' imaginative and critical thinking abilities in order to be able to write effectively and creatively (Nunan, 2003:88). Similarly, Meyers in Fauzi (2015: 7) states that writing is a process of discovering and organizing ideas, putting them on a paper, reshaping and revising them to express the writers' feelings or their daily activities such as writing letters, reports, and necessary tasks. Meanwhile, Graham and Perin (2007: 9) states that 
writing is a skill that draws on the use of strategies (such as planning, evaluating, and revising text) to accomplish a variety of goals and as a means of extending and deepening students' knowledge. Writing is used to show whether the students master a particular grammatical rule, rather than has a good idea about the subject matter (Nunan, 2003: 89).

To achieve a good writing, the teaching learning process of writing should concern on the teacher's role, principles of teaching writing, approaches to teaching writing, assessing writing, and learning materials of writing. The teachers have crucial roles to determine the success of the learning process in the writing class where the teacher gives ideas about how to make a good sentences and paragraphs (Nunan, 2003:88). Harmer (2007: 330) states that there are some roles that teacher must concern during process of the teaching of writing. First, the teacher should role as motivator to make the students enjoy the activities through creating the nice learning atmosphere, persuading the benefits of the activity, and encouraging them to have better efforts to achieve their best writing. Second, the teacher should be ready to become a resource. When the students are doing more extended writing tasks, the teacher must be ready to supply information and language needed by the students. Besides, the teacher must also ensure the students about the existence of the teacher to give them advice and suggestions in a constructive and tactful way. For example, in the process approach, the teacher facilitates the students' writing by providing input or stimulus. Last, the teacher must provide a positive feedback. Being a feedback provider, a teacher should respond positively to the content of what the students have written. The feedback given to the students must be based on what they students need at their level of studies.

Understanding the principles for teaching writing also leads success in class. According to Nunan (2003:92), there are some principles of the teacher in planning a course. First, understand the students' reasons for writing. The greatest dissatisfaction with writing instruction comes when the teacher's goals do not match the student's, or when the teacher's goals do not match those of the school or institution in which the students works. It is important to understand both and to convey goals to students in ways that make sense to them. Second, the teacher should provide opportunities for students to write. Practice writing should provide students with different types of writing as well. Short responses to a reading, journal entries, letter writing, summaries, poetry, or any type of writing find useful in the class should be practiced in class. Third, make feedback helpful and meaningful. Feedback should not entail "correcting" a student's writing. In order to foster independent writers, we can provide summary comments that instruct students to look for problems and correct them on their own. The last is clarifying how their writing will be evaluated. There are three types of rubrics that can be developed for assignments: Non-weighted rubric is the type of rubric provides descriptions of writing quality by level across other writing criteria; weighted rubric is similar to the impartial one, but it breaks the writing skills into categories and sub-categories; and holistic rubric describes in general terms the qualities of excellent, good, fair, and unsatisfactory assignments.

Teacher should also be aware of the different approaches in writing activities. Harmer (2007: 325) states that there are five type categories of classroom writing performance. It is, firstly, focusing on the aims of a task and in 
end of product. While teacher concentrates on process, we pay attention to the various stages that any pieces of writing go through. It includes spending time with learners on pre-writing phase, editing, redrafting, and publishing. Next, Writing and genre aims at which the students are going to study some exemplification texts before they embark on their own writing. Furthermore, creative writing suggests imaginative writing tasks such as writing poetry, stories, and plays. Writing as a cooperative activity also offers good result whether it is as part of a long process or as part of a short game like communicative activity.

Last necessity to create successful learning activities would be the right assessment. Harmer (2007: 379) states that assessment is used to measure the students' abilities to see if they can enter a course or institution. It means that by assessment the teacher can know information about the students' language ability during learning in the classroom. The teachers become the determinant in the outcome of students' writing. In doing assessment, the teachers should pay attention on some principles of classroom assessment. Nunan (2003: 314-316) states that there are some principles of classroom assessment, they are; making sure that the kind of assessment that is used by the teacher is appropriate for its intended purpose, making sure that the assessment that is used based on an explicit statement of the ability that the teacher assessing and clearly related to learning outcome, involving learners in assessment, and using variety of assessment method. Brown (2001: 357), states that there are six general categories of writing: content, organization, discourse, syntax, vocabulary, and mechanic. Those aspects of writing become the fundamental aspect in assessing writing. Below is the table of scoring rubric for rating composition tasks.

The aims of writing at Senior high school as illustrated in Indonesian national curriculum are being able to write and produce some kinds of genres of texts such as recount, report, procedure, narrative, news item, descriptive, analytical exposition, hortatory exposition, explanation, discussion, and spoof. They have to be able to write and produce some kinds of short functional texts and simple essay with the rhetoric steps accurately, fluently, and thanked by using a variety of written language in the context of everyday life. Recount text is a kind of text which written to explain to the reader about a series of activity in a past. Knapp (2005: 223), recount text basically is written out to make a report about an experience of a series of related event. The goal of recount text is to entertain or informing about the past activity to the reader. Muflicatul (2015: 25) states that recount text is a text concerning with the writers experience in the past activities. Knapp (2005: 223) states that a recount is written out to inform an event or to entertain people. Recount text has several elements, one of which is generic structures. According to Boardman in Natael (2014: 57), the steps for constructing of written recount text are that the first paragraph is called on orientation. It gives background information about who, what, where and when. The next paragraphs are record of events usually recounted in chronological order namely event 1 , event 2 , event 3 . Personal comment and or evaluative remarks are interspersed throughout the record of events named evaluation. And last, a re-orientation which "rounds off "the sequences of events or retell about what happened in the end. According to Boardman in Natael (2014: 57) the language features usually found in a recount are the use of nouns and pronouns to identify people, animals or things involved; the use of past action verbs to refer the events; the use of past 
tense to located events in relation to speaker`s or researcher's time; the use conjunctions and time connectives to sequence the event; the use of adverb and adverbial phrases to indicate place and time; and the use of adjectives to describe nouns.

However, the fact shows that many students in Senior High School find it difficult to write a sentence and explore the paragraph of recount text. The students are lack of ideas, lack of knowledge and also lack of vocabularies. They come from the result of students' assumption that writing is difficult and boring activity because they do not know how and what they should write. Second problem is the students' low interest. The students' low interest happened because they prefer to express their ideas orally than in the written forms. As the result, they can speak English fluently but they cannot write well. Third problem is the students' lack of motivation to write. This occurs because they do not have selvesconfidence. The students are afraid of making mistakes in writing including vocabulary, grammar, punctuation, organization and mechanism. The last problem is the students feel boredom because the teacher does not use the interesting media, methods or strategies in the learning process. Thus, it affects them not to easy in writing class.

Based on the problems, teachers must find a good solution such as using appropriate media to help the students in teaching writing. The use of media in teaching and learning process is able to make the lesson become meaningful, interesting, and understandable. One of the media is suitably applied in teaching writing is visual. Smaldino (2005: 9) states that visuals media are highly used to promote learning. They include diagrams on a poster, drawing on chalkboard, photographs or pictures, graphics in book, cartoons, etc. One of visual media that can be used in teaching and learning English is Comic Strips. According to Liu in Astra (2014: 15), a Comic Strip is "a series of pictures inside boxes that tell a story". Comic Strips are communicative, popular, accessible, readable, and they combine aesthetic perception with intellectual pursuit. Thus, by using Comic Strips facilitate the students to comprehend the content of the story by series of pictures in Comic Strips. Gavigan and Renyta (2015: 25-26) states that comic strips are short form comics which generally consist of three to eight panels. They usually appear in newspapers. Comic Strips consists series of picture in some panels that are interrelated to display a complete story which is suitable to be used in a class. Comic Strips also help the students to identify the elements of story like plot, character, and theme through visual and dialogue. By knowing the elements of the story, it is easier for students to write their own. The students can choose his or her own characters and develop stories alone or with partner. Brown, in Fika and Mirjam (2012: 184), states that Comic Strips meet this characteristic since they are series of pictures in which the students are expected to gain the ideas easily from the chronological order of the story. The students are also able to practice grammatical rules through this media. It can be done by changing direct speech in the speech balloon into indirect speech.

Comic Strips is an effective media to teach writing. It can be seen from the result of the journal that shows teaching writing using Comic Strips can improve students writing skill. The first is by Fika and Mirjam (2012) with the title "Comic Strips: A Study on the Teaching of Writing Narrative Texts to Indonesian EFL Students". The result of the journal shows that teaching writing using Comic 
Strips through Process-Genre Based Approach (PGBA) can successfully improve students' ability in writing. The findings also reveal that an effective implementation Comic Strips requires proper stories as well as sufficient teacher's guidance during the writing process. Besides, the mean scores of each aspect of writing: content, organization, grammar, vocabulary, and mechanic are also improved. All of the students of XII-language program can achieve the minimum passing criterion, 70. Second is by Yusda and Rasuna (2015) with the title "Enhancing the Students Writing Ability by Using Comic Strips". The result of the journal shows that the use of comic strips can enhance students writing skill in narrative text. Many students are motivated to write English narrative text by using comic strips both in group or individual works. The portraits of students' progress in writing English of narrative text of some cycles show that in the first cycle, only four of twenty five students who can write narrative texts as the successful indicator. In the second cycle, ten students are success; then in the third cycle, twenty two students could reach the value 80 or more as the criteria of success. The third is by Nur, Sriati and Muhsim (2015) entitles "Improving Writing Skill of the Eight Graders through Comic Strip". The result of the journal shows that the use of Comic Strips can improve the skill of the eighth grade students at SMP Negeri 9 Palu in writing a narrative text. It could be seen from the mean score of the pre-test (45.6) and the post-test (60.8). It indicates that the writing skill of eighth grade students at SMP Negeri 9 Palu improved.

Based on the discussion in the background of the study the objectives of the study are to describe the implementation and to find out the advantages and disadvantages of teaching writing recount text by using Comic Strips for the tenth grade students of SMAN I Jiwan in the schooling years of 2016/2017.

\section{METHOD}

In this study, the researcher uses qualitative approach. The researcher will analyze the classroom phenomena by using desciption data. The research took place at the tenth grade of SMAN I Jiwan in the schooling year of 2016/2017. The school is located in Ds. Teguhan, Kec. Jiwan, Kabupaten Madiun. The school is preferable because the students are less motivated to write English and having low interest in writing. It was carried out for 6 months from March until August 2017. The source of data is participant, document, and social condition. There are two participants used namely teacher and students. The researcher gets some information from the teacher and students through interviewing process. The researcher chooses students and English teacher of XD class as the participants.

In this research, the researcher observed the activities of the teaching learning process of XD class in SMAN I Jiwan and uses photographs to know the condition of the class during teaching learning process. Besides that, the researcher also uses lesson plan (RPP), students' attendance list, students' writing work, students score, and checklist of observation as the document in the research to know about the procedures, the advantages, and the disadvantages of using Comic Strips in teaching writing of recount text. The researcher used observation, interview, and documentation as the technique of collecting data. An indirect observation is used because the researcher does not actively participate in the classroom interactions and does not have a role to play other than observer. The researcher uses and fills checklist observation during the learning process. 
Moreover, the researcher uses voice recorder to record the student's activities in a class. The data got from observation, interview, and documentation in the research is checked using triangulation to measure the validity of the data. There are three kinds of sources for searching confirmation namelydirect obcervation, verbal report, anddocument.The researcher uses indirect observation and unstructured interview to the teacher and some students in tenth grade students as sample of the research. In analyzing the data, it used three concurrent flows activity of the data analyses called data condensation, data display, and drawing or verifying conclusion (Miles, 2014:31-33).

The researcher selects the entire data and only uses the data related to the research problems. The researcher only focuses on the using of Comic Strips to teach writing recount text. In this step, the researcher displays or shows the data observation, interview, and documentation in the form of description. The researcher display or show the description about the implementation of Comic Strips such as describing about the implementation, the advantages and the disadvantages of teaching writing recount text by using Comic Strips for the tenth grade of SMAN 1 Jiwan in schooling years of 2016/2017.In this step, the researcher reviews the finding of the research to give clear explanation of the aspect that the researcher's analysis in mainly about. By using verifying the data, the researcher concluded throughout the course. The conclusion of the description was taken after the researcher presented the data.

\section{FINDINGS AND DISCUSSION}

\section{The teaching procedure of teaching writing of recount text by using Comic Strips for the tenth grade students of SMAN 1 Jiwan in the school year of 2016/2017.}

There are some activities in the implementation of teaching writing recount text using Comic Strips. The first activity, the teacher introduces a Comic Strips media to the students.

Teacher: "In this morning we will learn a text using media that is Comic Strips. Do you know what is Comic Strips?"

Student: "Comic Strips adalah cerita bergambar Miss"

The second activity, the teacher distributes Comic Strips one by one to the students and asks them to read it. "Okay, now I will distribute to you one frame of Comic Strips one by one”. The students accept one frame of Comic Strips and read it. The third activity, the teacher gives some questions to the students related to the Comic Strips. "Class, do you know what is the title of this Comic Strips?", The students answer that the title of Comic Strips in many version like "an amazing day in the beach or holiday in the beach". "When did the writers holiday?". The students answer "Last week Miss". "So, what text tells about past activities? The students answer "Recount text Miss.

The forth activity, the teacher explains the material about the definition of recount texts and explains the purpose, generic structure, and language feature of recount text. "Can you mention the definition of recount text?" one of the students answer "the text to tell past experience" the teacher give explanation, "Recount text is a text that telling the reader about events or experience which happened in the past". Then, "Do you know the purpose of recount text?" some students 
answer "Untuk menceritakan kembali kejadian yang pernah terjadi di masa lampau Miss". The teacher gives explanation "The purpose of recount text is to inform or retell past events or experiences to the reader". Next, the teacher asks "Can you tell me the generic structures of recount text class". Some students give responses "Lupa Miss". The teacher gives explanation "Kemarin sudah diajarkan masak lupa, ya udah kita bahas lagi. There are three generic structures of recount text, "First is orientation tells who was involved, what happened, where the events took place, and when it happened. Second is events tells series of events that happened in the past. Third is Reorientation is consists of personal comment of the writer to the story". After that, the teacher asks "Can you mention the language features of recount text class". One of students answers "Using simple past tense Miss". The teacher gives explanation, "The language features of recount text are using simple past tense, persona participant, chronological connection, and adverb of time".

The fifth activity, the teacher gives a recount text paragraph and asks the students to analyze the generic structure and language feature of the text. "Okay, if you have understood my explanation about recount text. I will give you recount text based on the Comic Strips, you must analyze the text. You must find the orientation, events, reorientation and the language features of recount text". The teacher and the students analyze the text together.

The sixth activity, the teacher re-shares Comic Strips to the students. "Okay now I will give you Comic Strips again and I will distribute to you". The seventh activity, the teacher asks the students to write a recount text based on the Comic Strips. "After you read a Comic Strips, please make a recount text based on the Comic Strips with by paying attention the generic structures and also language features of recount text", the students pay attention and then starting to write a recount text based on the Comic Strips. The students get Comic Strips from the teacher. The eight activities, the teacher helps the students when they have difficulty in writing. "Do you find the difficulties class?" and the students give responds "No Miss".

The ninth activity, the teacher gives a command and suggestion to the students' handwriting. "Don't forget pay attention the pattern of recount text, there are many students using simple present tense. Please check again". The students pay attention to the teacher's command and suggestion "Yes Miss". The tenth activity, the teacher asks the students to write the final draft based on the teacher's suggestion and comment. "Okay after I give some suggestions and command about your work, please you can write again your work in other papers". The students pay attention about teacher's command and answer, "Yes Miss". The last activity, the teacher asks the students to submit their work. Okay, if you finish writing the final draft, you can submit your works". The students answer "Yes Miss" and submit their work.

There are some activities which are similar between the research and previous research by Fika and Mirjam (2013: 3-4) such as the teacher introduces Comic Strips to the students, the teacher gives students Comic Strips were adapted from local and foreign stories which suitable with the content of the story, the teacher gives again Comic Strips to the students, the teacher gives a test the students individually to write a story based on the Comic Strips, and the teacher analysis the product of students writing. 
The differences are in whilst activities in this research with the previous research above is the researcher changes, throws, and adds some steps in teaching recount text. Based on the procedure above begins with the teacher explains about narrative text and also the characteristics. To make the writing class more alive and help the students to generate ideas in pre writing, the researcher change it with the teacher explains Comic Strips media first to the students. Then, the teacher changes the material from narrative text become a recount text.

Moreover, to save time the learning process in the classroom, the researcher also throws some steps which is felt will spend time when implemented in the class such as the teacher asks the students to make a group consisting of four students, the teacher asks the group to write a story based Comic Strips that have they got, the teacher and the students discuss together about the students' handwriting, the teacher asks the students to write in pairs based on the story in the Comic Strips, the teacher and the students discuss together about the students' handwriting. Next, the researcher also adds some steps to make the learning process to be better such as the teacher gives a recount text paragraph and asks the students to analyze the generic structure and language feature of the text, the teacher helps the students when have difficulty in writing, the teacher asks the students to write the final draft based on the teacher's suggestion and comment. follows:

The procedures of teaching writing of recount text are summarized as

a. The teacher explains about what are narrative text and also the characteristics.

b. The teacher introduces Comic Strips to the students.

c. The teacher asks the students to make a group consisting of four students.

d. The teacher gives students Comic Strips were adapted from local and foreign stories which suitable with the content of the story.

e. The teacher asks the group to write a story based on Comic Strips that have they got.

f. The teacher and the students discuss together about the students' handwriting.

g. The teacher gives again Comic Strips to the students.

h. The teacher asks the students to write in pairs based on the story in the Comic Strips.

i. The teacher and the students discuss together about the students' handwriting.

j. The teacher gives the last Comic Strips to the students.

$\mathrm{k}$. Then the teacher gives a test the students individually to write a story based on the Comic Strips.

1. The last is the teacher analysis the product of students writing.

2. The Advantages of teaching writing recount text by using Comic Strips for the tenth grade students of SMAN 1 Jiwan in the school year of 2016/2017.

\footnotetext{
a. Comic Strips are considered good in assisting the students in understanding vocabulary.
} 
The first advantages of teaching writing recount text using Comic Strips is this technique is considered good in assisting the students in understanding vocabulary. It can be proved based on the interview toward English teacher and students of XD class. The teacher said that

"Media ini menurut saya sangat bagus mbak, dengan penerapan media ini di dalam kelas membuat siswa dapat memahami apa maksud kosa kata yang ada di dalam Comic tanpa melihat di kamus. Dengan melihat gambar yang ada di dalam comic, siswa dapat mengetahui apa maksud isi cerita tersebut karena biasanya gambar yang ada di dalam comic tersebut mencerminkan isi yang ada di dalam dialog. Jadi siswa dapat menebak kata tersebut melalui gambar yang dilihat di dalam comic.

It means that by using Comic Strips will help the students to guess the meaning of the word through the pictures because the pictures in the Comic Strips reflect the content of the dialogue. Moreover, based on the students interview also adds:

"Comic Strips Efektif diajarkan di kelas karena Comic Strips adalah media yang sangat menarik dan membantu kita untuk lebih mudah memahami kosa kata yang ada di dalamcerita. Kita dapat dengan mudah menebak arti kosa kata tanpa melihat di kamus dengan melihat gambar yang ada di dalam Comic.

It means that Comic Strips is an effective media using in the classroom because the students more easy to understand the meaning of the word by looking the pictures in Comic Strips without looking the dictionary.

In the results of students' writing work shows that almost all of students more creative in composing recount text because they can use a new vocabulary in writing stories which can be got from Comic Strips. It means that the students understand what the vocabulary means in the Comic Strips then they use the new vocabulary in composing a text. It is also supported by the result of research done by Fika and Mirjam (2012: 200) who state that "The use of comic strips is also considered good in assisting the students in understanding vocabulary since the picture and the dialog cooperate with each other meaning that most of the expressions shown by the characters reflect the content of the dialog. Therefore, the students can take advantage by guessing the words through the pictures". It shows that by using Comic Strips help the students to understand the meaning of the vocabulary by looking the pictures and dialogs which related each other.

\section{b. Comic Strips improve the students' motivation in writing class.}

The second advantages of teaching writing recount text using Comic Strips is this technique improve the students' motivation in writing class. It can be proved based on the interview toward English teacher and students of XD class. The teacher said:

"Menurut saya pembelajaran writing menggunakan media Comic Strips ini dapat meningkatkan motivasi siswa di dalam menulis mbak. Dialog yang ada di dalam Comic Strips sangat mudah dibaca dan dipahami oleh siswa ditambah lagi dengan gambar-gambar yang mencerminkan isi ceritanya sangat membantu dan menarik minat siswa di dalam menulis.

It means that by using Comic Strips media can attract and improve the students' motivation in writing class because the pictures in Comic Strips attract the 
students in making a text. The pictures in Comic Strips help the students to know the content of the story so it easier the students to compose a text. Moreover, the students add:

"Penggunaan Comic Strips dapat meningkatkan motivasi belajar dalam menulis karena Comic Strips adalah media yang menghibur jadi pembelajaran writing menjadi tidak membosankan lagi"

It means that by using Comic Strips in a class can increase the students' interest in learning to write because this media is an entertaining media. So the learning not bored anymore.

In the results of photograph shows that in the implementation of Comic Strips attracted the students' motivation in writing. Almost all of students pay attention with the teacher' explanation and follow the instruction to make a recount text. By using Comic Strips, students do their task more interesting and they done it leisurely. They enjoy the interesting pictures and simple conversations that they can found in the Comic.

By the use of media, the learning process better than before and they get interested after all. It is also supported by the result of research done by Lutfifati (2011) and Purwanitasari (2010) in Fika and Mirjam (2012: 199) who stated that the use of comic strips is effective to increase the students' writing achievement and stimulate the students' motivation in writing since it is completed with interesting pictures and chronological order of the story. According to Csabay in Yusda and Rasuna (2016: 616), Comic Strips can motivate the students to write a paragraph by the interesting story in Comic Strips, so it is build up students' confidence in the process of teaching learning. Yang in Yusda and Humola (2016: 616) states that Comic Strips is an educational tool in motivating students. Before students thought in words, they felt in pictures. They show that Comic Strips is effective media applied in the classroom because this media increase the students' ability in writing class. By the interesting pictures and the chronological of the stories stimulate the students' motivation in writing.

\section{c. Comic Strips makes the students comprehend the material easily.}

The third advantages of teaching writing recount text using Comic Strips makes the students comprehend the material easily. It can be proved based on the interview toward English teacher and students of XD class. The teacher said:

"Menurut saya siswa dapat memahami materinya dengan jelas dan mudah mbak karena di dalam Comic Stripsnya berisi penggalanpenggalan cerita yang singkat dan mudah dipahami oleh siswa. Jadi siswa cepat mengerti apa isi ceritanya"

It means that using Comic Strips media helps the students to comprehend the material clearly because in the media there are a pictures and a short of story that describes the content of the pictures so it facilitates the students easier to catch the content of the story. Moreover, the students said:

"Dengan adanya gambar di dalam Comic Strips memudahkan kita dalam memahami materi dengan jelas"

It means that the pictures in Comic Strips easier the students in comprehend the materials clearly.

The results of observation also shows that in the learning process makes the students fast to comprehend the materials clearly. It is caused the story in Comic 
Strips facilitate the students to catch the material which is explained the teacher; the students also show their effort in following the learning process with always answer the teacher' questions related to the Comic Strips. So it makes the learning process in sufficient within the specified time. It shows that Comic Strips as one of media is suitable applied in classroom because help the students to comprehend the material easily.

According to Budiman et al. (2012: 39-40, comic strips is a suitable media applied in writing class because Comic Strips are a perfect way for students to write in a good organization. Ferri and Qikurema (2013: 3-4) states that the students' composition is getting better in every writing task by using comic strips. Fika and Mirjam (2013: 185) states that Comic Strips through Process-Genre Based Approach (PGBA) could successfully improve students' ability in writing.It is because Comic Strips consist of story that has a beginning, middle, and end. Therefore, Comic Strips enable to help students to determine the organization of the text.

\section{d. The students are more enthusiastic to follow the teaching and learning process.}

The last advantages of teaching writing recount text by using Comic Strips makes the students are more enthusiastic follow the teaching and learning process. It can be proved based on the interview toward English teacher and students of XD class. The teacher said:

"Menurut saya Comic Strips adalah media yang bagus digunakan untuk mengajar menulis di kelas. Saya belum pernah mengajar menulis menggunakan media Comic Strips di kelas jadi siswa terlihat sangat antusias untukmengikuti proses pembelajaran ini.

It means that Comic Strips is a good media applied in the classroom because the students seem enthusiastic to make a recount text based on the picture of Comic Strips. Comic Strips media helps them to generate idea in composing recount text. So by using Comic Strips in a class make easy the students to compose a text then enthusiastic follow the teaching and learning process. Moreover, the students also said

"Kelebihannya yaitu dengan pembelajaran menulis seperti kemarin sedikit berbeda dengan yang sering dilakukan oleh Ibu guru karena baru kali ini diajarkan menggunakan media Comic Strips. Jadi pembelajaran menjadi lebih menyenangkan dan tidak membosankan".

It means that the advantages by using Comic Strips in teaching writing is the students more enthusiastic in the class because this is first taught in the classroom so the lesson more interesting and not bored.

The results of observation shows that during the teaching and learning process the students is very enthusiastic follow the learning process because the teaching writing become not monotonous. Comic strips which is given as the guidance for the students to write the recount text. The comic strips pictures help the students to know the elements of the story like plot, character, and theme through visual and dialogue. By knowing the elements of the story, it is makes the students easier to write recount text based on their understanding and their own ideas which get from the pictures. Therefore, the teaching and learning process 
become not monotonous because the students find a new atmosphere in writing class.

In the documentation of photograph also shows that all students very enthusiastic in a class because they feel it is a new atmosphere in learn writing. So they feel happy and very attracted to follow teaching learning process. While, in the checklist of observation filled by observer shows that the students follow all the activities in the teaching writing process. It means that the students is enthusiastic and attract to follow the implementation of teaching writing recount text using Comic Strips.

It is also supported by the result of research done by Fika and Mirjam (2012: 194) who states that "The first points as the strengths of the implementation of comic strips strategy is the students were very enthusiastic in paying attention to the comic strips and the story since every student got the comic strips. They could see the picture and the dialog clearly. It shows that by using Comic Strips in the teaching and learning process increase the students' enthusiastic in class.

\section{The Disadvantages of teaching writing recount text by using Comic Strips for the tenth grade students of SMAN 1 Jiwan in the school year of 2016/2017.}

\section{a. Some students who are lack of vocabulary does not understand the content of the story.}

The first disadvantages of teaching writing recount text using Comic Strips is some students who are lack of vocabulary does not understand the content of the story. It can be proved based on the interview toward English teacher and students of XD class. The teacher said:

"Anak-anak yang pemahaman gambarnya sulit akan mengalami double kesulitan, selain kesulitan di dalam mencerna apa isi cerita yang ada di dalam Comic Strips siswa juga akan kebingungan ketika untuk diminta menulis cerita".

It means that the students who have difficult to understand the picture will experience double troubles that are difficult to digest the content of stories in Comic Strips and they would also be difficult when writing a text. Moreover, students said:

"Kelemahan dari media Comic Strips ini yaitu kadang ada kosa kata yang tidak dimengerti di dalam cerita jadi susah untuk memahami isi di dalam cerita".

It means that some students get difficulties in vocabulary, lack of vocabulary make them difficult to understand the content of the story.

In the result of the students' writing work also shows that many students copied his friend's work. It means that many students who lack of vocabulary and grammar difficult to know the meaning of the story. So it makes the students also difficult to make a recount text then many of them copied his friend's work.

\section{b. Some students are still passive in a class.}

The second disadvantages of teaching writing recount text using Comic Strips is some students still passive in a class. It can be proved based on the 
observation and photographs. In the observation show that few students are still passive in the teaching and learning process. It is caused many of them joke and chat with their friends during the lesson. So it makes them have a low attention in the teaching and learning process. Moreover, the result of photographs shows that few students are lazy to make a recount text. They are passive to follow the teachers' explanation. Many of them just sit and wait for the work of his friends and then copied.

\section{CONCLUSION}

It can be concluded that there are introducing the media, explaining and analyzing the recount text, redistributing the media with other topic, asking the students to read and pay attention to, writing a recount text based on the Comic Strips given, monitoring the students' difficulties, correcting their mistakes on writing the text, writing the final draft based on the teacher's suggestion and comment, submitting the final writing, reviewing and giving feedback to the lesson, and closing.

There are some advantages in the implementation of teaching writing recount text by using Comic Strips for the tenth grade students of SMAN I Jiwan in the schooling year of 2016/2017. First is Comic Strips is considered good in assisting the students in understanding vocabulary. Second is Comic Strips can attract and improve the students' interest in writing class. Third is Comic Strips makes the students comprehend the material easily. The last is the students are more enthusiastic to follow the teaching and learning process.

Besides there are some disadvantages in the implementation of teaching writing recount text by using Comic Strips for the tenth grade students of SMAN I Jiwan in the schooling year of 2016/2017. First is some students who are lack of vocabulary does not understand the content of the story. So it makes the students also difficult to make a recount text then many of them copied his friend's work. Moreover, few students also still passive in the teaching and learning process. Many of them just sit then joke and chat with their friends. It makes them have a low attention in the teaching and learning process. So, the result of their writing gets a standard score.

\section{REFERENCES}

Ary, D., Jacobs, L. C., Sorensen, C., \&Razavieh, A. (2010). Introduction to Research in Education, ${ }^{\text {th }}$ Edition. United States Copyright Act.

Astra, A. W. (2014). Developing Comic Strips-Based Speaking Tasks for the Seventh Grade Students of SMP N 2 Temon in the Academic Year of 2013/2014. Thesis. Yogyakarta: English Education Department Faculty of Languages and Arts Yogyakarta State University.

Bogdan and Biklen.(2007). Qualitative Research Methods for the Social Sciences. Boston: Pearson Education.

Brown, H. Douglas. (2001). Teaching by Principles: An Interactive Approach to Language Pedagogy, $2^{\text {nd }}$ Edition. New York: Addison Wesley Longman, Inc. 
Brown, H. Douglas. (2004). Language Assessment: Principles and Classroom Practices. New York: Pearson Education.

Budiman, Mahdum, \&Wirda, B. (2012).Increasing the Ability of SMAN 12 Pekanbaru Students in Writing an Analytical Exposition Text through Comic Strips.Thesis.

Cresswell, John. W. (2009).Research Design: Qualitative, Quantitative, and Mixed Approaches, $3^{\text {rd }}$ Edition. United States of America: Sage Publications, Inc.

Fauzi, F. K (2015). Using Comic Strips to Improve the Writing Learning Process of the Eighth Grade Students of SMPN 2 Padangan, Bojonegoro in the Academic Year of 2014/2015. Thesis. Yogyakarta: English Education Study Program Faculty of Languages and Arts Yogyakarta State University.

Ferri, P. S., \& Qikurema, P. (2013). The Implementation of Comic Strips as Media in Teaching Writing Narrative Text for the Tenth Graders of Senior High School. Ejournal Unesa.

Fika, M., \& Mirjam, A. (2012). Comic Strips: A Study on the Teaching of Writing Narrative Texts to Indonesia EFL Students. TEFLIN Journal, 23 (2), 183-204.

Fraenkel, J. R., Wallen, N. E. \& Hyun, H. H. (2012).How to Design and Evaluate Research in Education. New York: The McGraw Hill.

Graham, S. \& Perin, D. (2007).Writing Next: Effective Strategies to Improve Writing of Adolescents in Middle and High School. A Report to Carnegie Corporation of New York. Washington. Dc: Alliance for Excellent Education.

Hadfield, J. \& Hadfield, C. (2008).Introduction to Teaching English. Oxford: Oxford University Press.

Harmer, Jeremy. (2007). The Practice of English Language Teaching, $4^{\text {th }}$ edition. Harlow: Pearson Education Limited.

Knapp, P. \& Watkins, M. (2005).Genre, Texts, Grammar: Technologies for Teaching and Assessing Writing. Sydney: University of New South Wales Press.

Miles, et al. (2014). Qualitative Data Analysis: A Methods Sourcebook. $3^{\text {th }}$ Edition. United States of America: Sage Publications, Inc.

Natael, S., Roswita, S., \&Hilman, P. (2014). The Effectiveness of Using Recount Text to Improve Writing Skill for Grade III Students ofKalam Elementary School 2 Pematangsiantar. IOSR Journal of Humanities and Social Science (IOSR-JHSS), 1(12), 56-64.

Nunan, D. (2003). Practical English Language Teaching. New York: The McGraw Hill.

Nur, H., Sriati, M., \& Muhsin. (2015). Improving Writing Skill of the Eight Graders through Comic Strips. E-Journal of English Language Teaching Society (ELTS), 3 (2), 1-11.

Richards, J.C. \& Renandya, W.A. (2002). Methodology in Language Teaching: An Anthology of Current Practice. Cambridge: United Kingdom. 
Journal of English Teaching Adi Buana, Vol. 03 No. 02, October 2018

Renyta, O. K. (2015). Using Comic Strips to Improve the Speaking Skill of Grade VIII Students of SMP N 15 Yogyakarta in the Academic Year of 2013/2014. Thesis. Yogyakarta: English Education Department Faculty of Languages and Arts Yogyakarta State University.

Smaldino, Sharon, Russel, \&Molenda, M. (2005). Instructional Technology and Media for Learning. Pearson: Merrill Prentice Hall.

Muflichatul, I. (2015). An Error Analysis of Using Action Verb in Recount Text Made By the First Year Students of SMA KARTIKA III-1 Banyubiru in the Academic Year 2013/2014. Thesis. English Department of Educational Faculty State Institute for Islamic Studies (STAIN) Salatiga.

Wahyuni, Sari. (2012). Qualitative Research Method: Theory and Practice. Jakarta: Salemba Empat.

Yin, Robert K. (2011). Qualitative Research from Start to Finish. New York: The Guilford Press.

Yusda, H., \& Rasuna, T. (2016). Enhancing the Students Writing Ability by Using Comic Strips. PROSIDING ICTTE FKIP UNS 2016, 1 (1), 614-623. 